Article

\title{
Effects of Vitamin E Supplementation on Reducing Chronic Hemolysis in Glucose 6 Phosphate Dehydrogenase (G6PD) Deficiency
}

\author{
Nayma Sultana ${ }^{1}$, Noorzahan Begum² ${ }^{2}$ Shelina Begum ${ }^{3}$, Sultana Ferdousi ${ }^{4}$, Taskina Ali ${ }^{5 .}$
}

\begin{abstract}
Background: Vitamin E works within the cell membrane as an antioxidant and may prevent destruction of RBC in G6PD deficient hemolytic anemia, which can be reflected by changes in peripheral blood film. Objective: To observe the role of vitamin E supplementation on restoring normal cell types in peripheral blood film in order to evaluate the role of this antioxidant vitamin in reducing chronic hemolysis in G6PD deficient patients. Method: Total 102 subjects, age range from 5-40 years of both sexes were included in the study. Among them 68 were G6PD enzyme deficient patients, of whom 34 were in non-supplemented group (Group B) and 34 were in supplemented group (Group C). Both group $B$ and $C$ were divided into Group $B_{1}$ and $C_{1}$ (on day 1 ) and also into $B_{2}$ and $C_{2}$ (on day 60 ) respectively. Supplemented group received vitamin $\mathrm{E}$ supplementation for 60 consecutive days (800 IU/day for adult and $400 \mathrm{IU} /$ day for children in a divided dose i,e. 4 times daily). Age and sex matched 34 apparently healthy subjects with normal G6PD level (Group A) were also taken to observe baseline data. Determination of Erythrocyte G6PD level and preparation of peripheral blood film were done on day 1 for all groups and also on day 60 in deficient groups. Results: Percentage of subjects with presence of some abnormal red cells in peripheral blood film was significantly higher in patients of hemolytic anemia with G6PD deficiency in comparison to that of healthy control. After supplementation with vitamin E (i,e. on day-60) this percentage was significantly decreased towards those of healthy control in their supplemented group in comparison to that of pre-supplemented (day-1) and nonsupplemented groups. Conclusion: Some abnormal red cells may be found in peripheral blood film of G6PD deficient patients, improvement of which occur following vitamin E supplementation, and thereby indicates role of this antioxidant vitamin in reducing the rate of hemolysis.
\end{abstract}

Key words: G6PD deficiency, Peripheral blood film, Vitamin E

J Bangladesh Soc Physiol. 2011 June; 6(1): 70-76 For author affiliations, see end of text.

http://www.banglajol.info/index.php/JBSP

Introduction

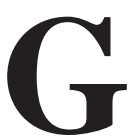

lucose-6-Posphate Dehydrogenase (G6PD) deficiency is one of the most common enzymopathy affecting erythrocyte metabolism. Worldwide more than 400 million people are affected by this enzymopathy. ${ }^{1}$ The most common clinical consequences of G6PD deficiency are neonatal jaundice and sporadic hemolytic crisis, caused by number of drugs, infections or ingestion of fava beans. The most significant consequence

J Bangladesh Soc Physiol. 2011 June; 6(1): 
of this enzyme deficiency is hemolytic anemia. ${ }^{2}$. The prevalence of G6PD enzyme deficiency is higher in Africa, the Mediterranean region, the Middle East, The South-East Asia and indigenous population of the Indian subcontinent ${ }^{3}$.

A decrease in hemoglobin concentration with a marked increase in reticulocyte count is the usual findings in G6PD deficient patients ${ }^{4}$. In addition, a reduction in mean half-life of RBC may also be found in this type of chronic hemolytic anemia ${ }^{5}$. In G6PD deficiency a normal appearance of RBC is a common finding in peripheral blood film ${ }^{6}$. However, sometimes macrocytes with slight hypochromic appearance may also be found in peripheral blood film. Moreover, target cells, tear drop cells, nucleated red cells, schistocyte, Heinz bodies, erythrocytes fragmentation and polychromasia are also found in peripheral blood film in this group of chronic hemolytic anemic patients ${ }^{7}$.

However, vitamin-E is one of the major lipid soluble anti-oxidant. It prevents oxidation of polyunsaturated fatty acids, thus protects cells from oxidative stress-induced lyses ${ }^{8}$. Deficiency of vitamin- $E$ is a common feature in genetic anemia, due to its increase consumption ${ }^{8,9}$. Supplementation of Vitamin-E may also have an important role in maintaining red cell membrane integrity thereby preventing hemolysis and improving red blood cells survival ${ }^{4,5}$. Again, this vitamin may also cause a sustained improvement in hemoglobin concentration, and reticulocyte count $^{5,10}$. Moreover, normal red blood cell may also be found in peripheral blood film after oral supplementation of this vitamin ${ }^{11}$.

In Bangladesh, there is lack of adequate information regarding G6PD deficient anemic patients. A few data regarding the hematological parameters of G6PD enzyme deficient patients are available ${ }^{12}$. But a few is known regarding effects of vitamin $E$ supplementation on these G6PD deficient patients. Therefore, the present study was undertaken to observe the changes in red cell morphology found in peripheral blood film in G-6-PD enzyme deficient patients both before and after supplementation of vitamin $\mathrm{E}$, to explore its role in preventing red cell lysis and thereby maintains their normal features in these enzyme deficient patients. The findings of the study therefore may be helpful to create awareness about the deficiency of G6PD enzyme in anemic patients as well as the role of vitamin $\mathrm{E}$ in minimizing the risk of complications. Moreover, it can provide information to clinicians for better management of these patients.

\section{Methods}

The present prospective interventional study was carried out in the Department of Physiology, Bangabandhu Sheikh Mujib Medical University (BSMMU), Dhaka between July 2005 to June 2006. In this study, a total number of 102 subjects with age ranged from 5 to 40 years of both sexes were included. Among them 68 were patients of hemolytic anemia with blood G6PD level below the normal reference range ${ }^{13}$, of whom 34 were in non-supplemented group (control group- Group B) and 34 were in supplementation and was considered as supplemented group (study groupGroup C). Both of these groups were studied twice that is on the first day of their visit (group $\mathrm{B}_{1}$ and $\mathrm{C}_{1}$ ) and also on day 60 (group $\mathrm{B}_{2}$ and $\mathrm{C}_{2}$ ) respectively.The supplemented group received vitamin E supplementation for 60 consecutive days at a dose of $800 \mathrm{IU} /$ day for adult and 400 IU/day for children $\leq 12$ years in a divided dose i,e. 4 times daily ${ }^{14,4}$. Again, age and sex matched 34 apparently healthy subjects with normal blood G6PD level were also taken to observe the baseline data (healthy control-Group A) and also for comparison. All the G6PD deficient patients were selected from Out Patient Department (OPD) of Hematology, BSMMU, Dhaka, and all the healthy subjects were selected from personal contact. All the subjects belonged to middle and lower middle socio-economic status. Patients with acute hemolytic episode or received blood transfusion in the last two months and b thalassemia trait were excluded from the study. The objectives and benefits of the study were 
explained to all the subjects to ensure their voluntary participation and a written informed consent was taken from each subject prior to the study. Two (2) ml of blood was taken in an EDTA test tube for determination of erythrocyte G6PD level and some hematological parameters.

Erythrocyte G6PD level was determined by spectrophotometric method and peripheral blood film was prepared and observed under the microscope of all the subjects on day 1(one) of their $1^{\text {st }}$ visit and in G6PD enzyme deficient groups of subjects also on day-60. Data were compared among healthy control, supplemented, nonsupplemented and also within supplemented groups just before and after supplementation.
Data were expressed as Mean \pm SD. Independentsample (unpaired) ' $t$ ' test, paired-sample ' $t$ ' test and $\chi^{2}$ test were done as the tests of significance wherever applicable. The statistical analysis was done by using SPSS programme version 12 and p value $<0.05$ was considered as significant.

\section{Results}

Hemoglobin concentration was significantly $(\mathrm{p}<0.001)$ increased and reticulocyte count was significantly $(\mathrm{p}<0.001)$ decreased in group $\mathrm{C}_{2}$ in comparison to those of group $\mathrm{C}_{1}$ and $\mathrm{B}_{2}$. Whereas, these values were almost similar and no significant differences were observed between group $\mathrm{B}_{1}$ and $\mathrm{B}_{2}$ (Table I).

Table I :Mean ( \pm SD) Hb concentration, reticulocyte count and G6PD level in different study groups $(\mathrm{n}=102)$

\begin{tabular}{lccc}
\hline Groups & $\begin{array}{c}\mathrm{Hb} \\
(\mathrm{g} / \mathrm{dl})\end{array}$ & $\begin{array}{c}\text { Reticulocyte } \\
(\%)\end{array}$ & $\begin{array}{c}\text { G6PD } \\
\left(10^{12} \mathrm{RBC}\right)\end{array}$ \\
\hline $\mathrm{A}(\mathrm{n}=34)$ & $14.26 \pm 1.44$ & $1.31 \pm 0.48$ & $191 \pm 18.8$ \\
$\mathrm{~B}_{1}(\mathrm{n}=34)$ & $10.15 \pm 0.94$ & $3.06 \pm 0.44$ & $105 \pm 9.38$ \\
$\mathrm{~B}_{2}(\mathrm{n}=34)$ & $10.15 \pm 0.86$ & $3.09 \pm 0.44$ & $105 \pm 9.74$ \\
$\mathrm{C}_{1}(\mathrm{n}=34)$ & $10.34 \pm 1.00$ & $2.79 \pm 0.55$ & $105 \pm 10.09$ \\
$\mathrm{C}_{2}(\mathrm{n}=34)$ & $13.06 \pm 0.83$ & $1.43 \pm 0.48$ & $108 \pm 8.5$ \\
\hline
\end{tabular}

Statistical analysis:

\begin{tabular}{llll}
\hline Groups & & P value \\
\hline $\mathrm{A} \mathrm{Vs} \mathrm{B}_{1}$ & $0.0000^{* * * *}$ & $0.000^{* * *}$ \\
$\mathrm{~A} \mathrm{Vs} \mathrm{C}_{1}$ & $0.000^{* * *}$ & $0.000^{* * *}$ & $0.000^{* * *}$ \\
$\mathrm{~A} \mathrm{Vs} \mathrm{B}_{2}$ & $0.000^{* * *}$ & $0.000^{* * *}$ & $0.000^{* * *}$ \\
$\mathrm{~A} \mathrm{Vs} \mathrm{C}_{2}$ & $0.002^{* *}$ & $0.000^{* * *}$ \\
$\mathrm{~B}_{1} \mathrm{VsC}_{1}$ & $0.000^{* * *}$ & $0.495^{\mathrm{ns}}$ & $0.588^{\mathrm{ns}}$ \\
$\mathrm{B}_{2} \mathrm{VsC}_{2}$ & $0.413^{\mathrm{ns}}$ & $0.000^{* * *}$ & $0.000^{* * *}$ \\
$\mathrm{~B}_{1} \mathrm{Vs} \mathrm{B}_{2}$ & $0.000^{* * *}$ & $0.350^{\mathrm{ns}}$ & $0.082^{\mathrm{ns}}$ \\
$\mathrm{C}_{1} \mathrm{Vs} \mathrm{C}_{2}$ & $0.946^{\mathrm{ns}}$ & $0.000^{* * *}$ & $0.000^{* * *}$ \\
\hline
\end{tabular}

Group $\mathbf{A}=$ Healthy subjects for baseline and control.

Group $\mathbf{B}=$ Hemolytic anemic patients with G6PD deficiency (Control) -nonsupplemented group.

Group $\mathbf{C}=$ Hemolytic anemic patients with G6PD deficiency (Experimental); (supplemented group)

- $\quad \mathrm{B}_{1}$ and $\mathrm{C}_{1}=$ On day $1 ; \mathrm{B}_{2}$ and $\mathrm{C}_{2}=$ On day 60

$* * *=\mathrm{p}<0.001$.

$\mathrm{p}<0.05$. ns $=$ Not significant. 
The percentage of subjects with abnormal peripheral blood film was significantly $(\mathrm{p}<0.001)$ higher in group $B_{1}$ and $C_{1}$ than that of group $A$. Again, the percentage of subject was almost similar in group $\mathrm{B}_{1}$ and $\mathrm{B}_{2}$, and the difference was not statistically significant. However, after supplementation of vitamin $\mathrm{E}$ the percentage of the subjects with normal peripheral blood film were also increased significantly $(\mathrm{p}<0.001)$ in group $\mathrm{C}_{2}$ in comparison to those of group $\mathrm{C}_{1}$ and $\mathrm{B}_{2}$. (Table II).

Some abnormal cells like, macrocytic hypochromic cells, nucleated red blood cells, target cells, polychromatic cells, tear drop cells, Heinz body, erythrocyte fragmentations were present in maximum percentage of the subjects of group $B_{1}$ and $C_{1}$. After supplementation, percentage of subjects with these abnormal red cells was found to be decreased in group $\mathrm{C}_{2}$. In addition to this, some other abnormal red cells like microcytic hypochromic, schistocytes, spherocytes were also present in some of the subjects of group $B_{1}$ and $C_{1}$. But after supplementation no such cells were observed in group $\mathrm{C}_{2}$. On the contrary, no such decrease in percentage of subjects with abnormal red cells was observed in group $\mathrm{B}_{2}$ on day 60 Table-III.

Table II: Distribution of study subjects by peripheral blood film in different study groups $(\mathrm{n}=102)$

\begin{tabular}{lccc}
\hline Groups & $\mathrm{n}$ & $\begin{array}{c}\text { Normal } \\
\text { no. }(\%)\end{array}$ & $\begin{array}{c}\text { Abnormal } \\
\text { no. }(\%)\end{array}$ \\
\hline $\mathrm{A}$ & 34 & $34(100 \%)$ & $0(0 \%)$ \\
$\mathrm{B}_{1}$ & 34 & $7(20.6 \%)$ & $27(79.4 \%)$ \\
$\mathrm{B}_{2}$ & 34 & $6(17.6 \%)$ & $28(82.4 \%)$ \\
$\mathrm{C}_{1}$ & 34 & $9(26.5 \%)$ & $25(73.5 \%)$ \\
$\mathrm{C}_{2}$ & 34 & $25(73.5 \%)$ & $9(26.5 \%)$ \\
\hline
\end{tabular}

Statistical analysis:

\begin{tabular}{lc}
\hline Groups & p value \\
\hline $\mathrm{A} \mathrm{Vs} \mathrm{B}_{1}$ & $0.000^{* * *}$ \\
$\mathrm{~A} \mathrm{Vs}_{1}$ & $0.000^{* * *}$ \\
$\mathrm{~A} \mathrm{Vs} \mathrm{B}$ & $0.000^{* * *}$ \\
$\mathrm{~A} \mathrm{Vs} \mathrm{C}_{2}$ & $0.001^{* *}$ \\
$\mathrm{~B}_{1} \mathrm{Vs} \mathrm{C}_{1}$ & $0.567^{\text {ns }}$ \\
$\mathrm{B}_{1} \mathrm{Vs} \mathrm{B}_{2}$ & $0.758^{\text {ns }}$ \\
$\mathrm{B}_{2}$ vs $_{2}$ & $0.000^{* * *}$ \\
$\mathrm{C}_{1}$ vs $_{2}$ & $0.000^{* * *}$ \\
\hline
\end{tabular}

Group $\mathbf{A}=$ Healthy subjects for baseline and control.

Group $\mathbf{B}=$ Hemolytic anemic patients with G6PD deficiency (Control)

- nonsupplemented group.

$\mathrm{B}_{1}$ and $\mathrm{C}_{1}=$ On day $1 ; \quad \mathrm{B}_{2}$ and = On day 60

Group $\mathbf{C}=$ Hemolytic anemic patients with G6PD deficiency (Experimental)

- supplemented group.

= On day $1 ; \quad=$ On day 60

${ }^{* * *}=$ Significant at $\mathrm{p}<0.001{ }^{* *}=$ Significant at $\mathrm{p}<0.01 \mathrm{~ns}=$ Not significant.

$\mathrm{n}=$ Total number of subjects. 
Article

Table III: Different cell types in subjects with abnormal peripheral blood film

\begin{tabular}{lcccc}
\hline Peripheral blood film & \multicolumn{4}{c}{ Groups } \\
\cline { 2 - 5 } & $\mathrm{B}_{1}(\mathrm{n}=34)$ & $\mathrm{B}_{2}(\mathrm{n}=34)$ & $\mathrm{C}_{1}(\mathrm{n}=34)$ & $\mathrm{C}_{2}(\mathrm{n}=34)$ \\
& $\mathrm{No.}(\%)$ & No. (\%) & No. (\%) & No. (\%) \\
\hline Macrocytic hypochromic cells & $12(35 \%)$ & $14(41 \%)$ & $14(41 \%)$ & $4(12 \%)$ \\
Nucleated red cells & $10(29 \%)$ & $12(35 \%)$ & $13(38 \%)$ & $03(9 \%)$ \\
Target cells & $06(18 \%)$ & $08(23 \%)$ & $06(18 \%)$ & $02(6 \%)$ \\
Teardrop cells & $05(15 \%)$ & $06(18 \%)$ & $05(15 \%)$ & $1(3 \%)$ \\
Microcytic hypochromic cells & $03(9 \%)$ & $04(12 \%)$ & $03(9 \%)$ & $0(0 \%)$ \\
Schistocytes & $04(12 \%)$ & $05(15 \%)$ & $03(9 \%)$ & $0(0 \%)$ \\
Heinz body & $05(15 \%)$ & $06(18 \%)$ & $05(115 \%)$ & $1(3 \%)$ \\
Erythrocyte fragmentation & $05(15 \%)$ & $05(15 \%)$ & $05(15 \%)$ & $1(3 \%)$ \\
Spherocytes & $03(9 \%)$ & $04(12 \%)$ & $03(9 \%)$ & $0(0 \%)$ \\
Polychromasia & $06(18 \%)$ & $06(18 \%)$ & $06(18 \%)$ & $01(3 \%)$ \\
\hline
\end{tabular}

\section{Discussion}

In this study significantly lower hemoglobin level and higher reticulocyte count with presence of some abnormal red cells in peripheral blood film were observed in patients with G6PD deficiency in comparison to those of healthy control. These findings are in consistent with those of some other researchers of different countries ${ }^{4,7}$. On the contrary, a normal hemoglobin level and reticulocyte counts were also reported by some other investigators ${ }^{15,16}$, and this discrepancy might be due to minor subclinical hemolysis.

Again, after 60 days supplementation of vitamin $\mathrm{E}$, hemoglobin level was significantly increased whereas, reticulocyte count and number of subjects with abnormal red cells were significantly decreased towards those of healthy control. Similar observations were also reported by some other researchers in G6PD deficient patients ${ }^{10,11}$.

In G6PD deficiency oxidation of polyunsaturated fatty acid of the RBC membrane may increase its susceptibility to hemolysis ${ }^{2,3}$. It has also been suggested that, presence of various abnormal red cells in peripheral blood film were due to changes in membrane integrity which might be the possible cause of early destruction of RBC in this type of patients ${ }^{9,10}$. Therefore, decreased level of hemoglobin and presence of abnormal red cell types in peripheral blood film may be the usual features in hemolytic anemia with G6PD deficiency as a consequence of excessive hemolysis ${ }^{10,17}$. However reticulocytosis may be caused by shorter red cell life span and subsequent increased rate of erythropoiesis to compensate hemolysis in this enzyme deficient patients ${ }^{4}$.

In this study significant number of subjects with abnormal red cell type in peripheral blood film, along with lower hemoglobin level and higher reticulocyte count in G6PD deficient groups, indicate red cell hemolysis. Defect of membrane integrity is most likely to be the cause of hemolysis as indicated by the presence of abnormal red cell types in peripheral blood film in G6PD deficient patients. However deficiency of this enzyme causes excessive hemolysis which is further supported by decreased Hb level and increased reticulocyte count in these patients. However, vitamin E, is an effective natural, lipid soluble antioxidant and protects the cell membrane from peroxidative damage ${ }^{18}$. Other workers suggested that, high dose of vitamin $\mathrm{E}$ 
scavenges free radicals, thus prevents early premature destruction of RBC and ultimately prevents formation of abnormal red cells ${ }^{14}$. However, improvement of all the study parameters towards the normal level by 60 days supplementation of vitamin $\mathrm{E}$ in the patients of present study is suggestive of these evidences.

\section{Conclusion}

Therefore, this study concludes that some abnormal red cells may be found in peripheral blood film in G6PD deficiency due to a higher rate of chronic hemolysis. Again, supplementation of vitamin E may decrease hemolysis to some extent due to its antioxidant property and thus restore normal red cell types in peripheral blood film. However, determination of vitamin E level, red cell half-life and long time supplementation of vitamin $E$ with larger sample size may be helpful to draw any definite conclusion.

\section{Acknowledgement}

Authors of the study are thankful to the G6PD deficient patients for their active co-operation and also to the Department of Physiology BSMMU, Dhaka for supporting us to conduct the study.

\section{Author Affiliations}

1. *Nayma Sultana, Assistant Professor, Physiology, Sir Salimullah Medical College, Mitford, Dhaka, Bangladesh. Email: nayma_sultana@yahoo.com

2. Professor Dr. Noorzahan Begum, Professor, Department of Physiology, Bangabandhu Sheikh Mujib Medical University (BSMMU), Dhaka, Bangladesh. Email: noorzahan52@gmail.com

3. Professor Dr. Shelina Begum. Professor \& Chairman, Department of Physiology, Bangabandhu Sheikh Mujib Medical University (BSMMU), Dhaka, Bangladesh. Email: shelina1982@gmail.com

4. Dr. Sultana Ferdousi, Associate professor, Department of Physiology, Bangabandhu Sheikh Mujib Medical University (BSMMU), Dhaka, Bangladesh.Email: sferdousiratna@gmail.com

5. Dr.Taskina Ali. Assistant Professor, Department of Physiology, Bangabandhu Sheikh Mujib Medical University (BSMMU), Dhaka, Bangladesh. Email: taskinadr@gmail.com

*for correspondence

J Bangladesh Soc Physiol. 2011 June; 6(1): 70-76

\section{References:}

1. Luzzato L, Mehta A, Meloni T. Hemoglobin and Haptoglobin in G6PD deficiency. Br J Haematol 1995; 91: 511-12.

2. Champe PC, Harvey RA, Ferrier DR. Lippincott's Illustrated Reviews. $3^{\text {rd }}$ ed. New Delhi: JP Brothers Medical Publishers (P) LTD; 2005. p.149

3. Smith ECG. Disorders of red cell metabolism. In: A.V. Hoffbrand, D. Oatovsky, and E.G.D. Tuddenham. Postgraduate hematology, Oxford: Blackwell publishing Ltd. 2005.

4. Hafez M, Amar ES, Zedan M, Hammad H, Sorou AH, Desouky SA, Gami N. Improved erythrocyte survival with combined vitamin $\mathrm{E}$ and selenium therapy in children with glucose-6-phosphate dehydrogenase deficiency and mild chronic hemolysis. J Pediatr 1986;108: 558-61.

5. Usberti M, Gerardi GM, Micheli AM, Piola T, Bufano G, Gaggia, P et.al. Effects of a vitamin E-bonded membrane and of glutathione on anemia and erythropoietin requirements in hemodyalysis patients. J Nephrol 2002;15: 558-64.

6. Burka RE, Weaver Z, Marks AP. Clinical spectrum of hemolytic anemia associated with glucose-6phosphate dehydrogenase deficiency. Ann Intern Med 1966; 64: 817-25.

7. Zinkham HW, Lenhard ER. Metabolic abnormalities of erythrocyte from patient with congenital nonspherocytic hemolytic anemia. J pediatr 1959; 80: 319-36 .

8. Chan AC, Chow CK, Chiu D. Interaction of antioxidant and their implication in genetic anemia. Proc Soc Exp Biol Med 1999; 222(3): 274-82.

9. Hasanato RMW. Zinc and antioxidant vitamin deficiency in patients with severe sickle cell anemia. Ann Saudi Med 2006;26 (1): 17-21.

10. Eldamhougy S, Elhelw Z, Yamamah G, Hussein L, Fayyad I, Fawzy D. The vitamin E status among glucose-6-phosphate dehydrogenase deficient patients and effectiveness of_oral vitamin E. Int $\mathrm{J}$ Vitam Nutr Res 1988; 58(2): 184-88.

11. Jaja SI, Aigbe PE, Gbenebipse S, Temiyp EO. Changes in erythrocytes following supplementation with alpha-tocopherol in children suffereing from sickle cell anemia. Niger Postgrad Med J 2005; 12(2): 110-14. 
12. Razzak M. Study on some aspects of hematological indices in G6PD enzyme deficient and non-deficient hemolytic anemia [M Phil thesis] [Dhaka]: Bangabandhu Sheikh Mujib Medical University; 2003. 75p.

13. Milne DB. Trace elements. In: Burtis CA and Ashwood ER editors. Tietz text book of clinical chemistry. Philadelphia: WB Saunders company; 2001. p. 568-83.

14. Spielberg SP, Boxer LA, Corash LM, Schulman JD. Improved erythrocyte survival with high dose vitamin $\mathrm{E}$ in chronic hemolyzing G6PD and glutathione synthetase deficiencies. Ann Intern Med 1979; 90: 53-54.

15. Karunanithy R, Saha N, Ng SE. Serum and red blood cell magnesium, copper and zinc content in G6PD deficiency. Am J Hematol 1990;35:136-38.
16. Ishay DB, Izak G. Chronic hemolysis associated with glucose 6-phosphate dehydrogenase deficiency.J Lab Clin Med 1964;63(6):1002-08.

17. May J, Mayer CG, Grofterlinder L, Ademowo OG, Mockenhaupt FP, Olumese PE, Falusi AG, Luzzatto L, Bienzle U. Red cell glucose 6-phosphate dehydrogenase status and pyruvate kinase activity in a Nizerian population.Trop Med Int Health 2000;5(2):119-23.

18. Gumustekin K, Chiftci M, Coban A, Altikat S, Aktas O, Gul M, Timur H, Dane S. Effects of nicotine and vitamin $\mathrm{E}$ on glucose-6-phosphate dehydrogenase activities in some rat tissues in vivo and in vitro. $\mathrm{J}$ Enzyme Inhib Med Chem 2005; 20(5): 497-502. 